\title{
Problematika Ontologis Pendidikan Islam
}

\author{
Syaripudin Basyar \\ UIN Raden Intan Lampung
}

\begin{abstract}
Theefforts to understand ontological meaning of Islamic education are not easy, furthermore the nature of Islamic education meaning is intended as an abstraction integrity of meaning that is accepted ideological, theoretical, and empirical. The existence of Islamic education is always in contact and grappling with the reality surrounding them. In historical perspective, the struggle between Islamic educations with sociocultural realities faces two possibilities: influences or is influenced. The consequence is that Islamic education can be defined as a process of enculturation and or facilitation efforts (medium). If referring to the terms of Islam, Islamic education is personified to the term attarbiyah, at-ta'lim, at-ta'dib and ar-riyadah. Each of these terms has different accentuation meanings although it has the same outline. In understanding Islamic education, basic education and its goal formulation becomes noteworthy. Since the basis and purpose of demarcation will distinguish with other educations.
\end{abstract}

Keywords: Ontological meaning, at-tarbiyah, at-ta'lim, at-ta'dib dan arriyadah, basic and purpose of Islamic education.

\begin{abstract}
Abstrak
Upaya memahami makna ontologis pendidikan Islam tidak mudah, terlebih lagi sifat makna pendidikan Islam dimaksudkan sebagai abstraksi integritas makna yang diterima secara ideologis, teoritis, dan empiris. Keberadaan pendidikan Islam selalu bersinggungan dan bergulat dengan realitas di sekitarnya. Dalam perspektif historis, perjuangan antara pendidikan Islam dengan realitas sosio-budaya menghadapi dua kemungkinan: pengaruh atau dipengaruhi. Konsekuensinya adalah bahwa pendidikan Islam dapat didefinisikan sebagai proses enkulturasi dan atau usaha fasilitasi (sedang). Jika mengacu pada ketentuan Islam, pendidikan Islam dipersonifikasikan dengan istilah attarbiyah, at-ta'lim, at-ta'dib dan ar-riyadah. Masing-masing istilah ini memiliki arti aksentuasi yang berbeda meskipun memiliki garis yang sama. Dalam memahami pendidikan Islam, pendidikan dasar dan perumusan tujuannya menjadi penting. Karena dasar dan tujuan demarkasi akan membedakan dengan pendidikan lain.
\end{abstract}

Kata kunci: Makna ontologis, at-tarbiyah, at-ta'lim, at-ta'dib dan ar-riyadah, dasar dan tujuan pendidikan Islam. 


\section{Pendahuluan}

Secara makro, eksistensi pendidikan Islam senantiasa bersentuhan dan bergulat dengan realitas yang mengitarinya. Dalam perspektif historis, pergumulan antara pendidikan Islam dengan realitas sosio-kultural menemui dua kemungkinan:

1. Pendidikan Islam memberikan pengaruh terhadap lingkungan sosiokultural, dalam arti memberikan wawasan filosofi, arah pandangan, motivasi perilaku, dan pedoman perubahan sampai terbentuknya suatu realitas sosial baru. ${ }^{1}$

2. Pendidikan Islam dipengaruhi oleh realitas perubahan sosial, oleh lingkungan sosio-kultural, dalam arti penentuan sistem pendidikan, institusi dan pilihan-pilihan prioritas, juga eksistensi dan aktualiasasi dirinya. ${ }^{2}$

Pada dasarnya ada dua pengertian tentang pendidikan, yang seringkali diperdebatkan, yakni:

1. Yang berpandangan bahwa pendidikan pada dasarnya adalah merupakan proses pewarisan, penerusan, dan sosialisasi perilaku individual maupun sosial, yang telah menjadi model anutan masyarakat secara baku.

2. Yang mengartikan pendidikan sebagai upaya fasilitatif yang memungkinkan terciptanya situasi atau lingkungan dimana potensipotensi dasar yang dimiliki anak-didik dapat berkembang sesuai dengan tuntutan kebutuhan mereka pada zaman dimana mereka harus survive.

Dua sudut pandang yang berbeda tentang pengertian pendidikan ini, masing-masing mempunyai implikasi yang luas terhadap penyelenggaraan pendidikan secara praktikal selama ini. Di lingkungan lembaga pendidikan Islam sekarang ini rasanya penekanan pada pengertian yang "pertama" tadi lebih kuat daripada pengertian yang "kedua", sehingga pendidikan diterjemahkan sebagai usaha mencetak anak-didik dengan sebuah model idola yang bersifat statis. Lain halnya jika penekanan pengertian pada yang "kedua", akan memungkinkan lebih banyak anak-didik untuk menemukan profil dirinya sendiri yanglebih actual dalam konteks lingkungan dan waktu dimana mereka sedang atau akan mengambil peran dalam hidupnya.

\footnotetext{
${ }^{1}$ A. Mukti Ali, Ijtihad, dalam Pandangan Muhammad Abduh, Ahmad Dahlan dan Muhammad Iqbal, Jakarta: Bulan Bintang, 1990. dan H.A.R. Gibb, Modern Trends In Islam, New York: Octagon Book, 1978. Hal 98

${ }^{2}$ Azyumardi Azra" "Modernisasi Pendidikan Islam dan Epistemologi Ilmu", Makalah Seminar Internasional tentangModernisasi Pendidikan Islam; Sistem, Metodologi dan Materi, ISID Gontor, 31 Agustus, 1996, hal 31
} 


\section{Pembahasan}

Formulasi hakikat pendidikan Islam tidak boleh lepas begitu saja dari ajaran Islam yang tertuang dalam al-Qurean dan As-Sunnah, karena kedua sumber tersebut merupakan pedoman otentik dalam penggalian khazanah keilmuan dalam pandangan Islam.Secara semantik, termenologi "pendidikan" dalam konteks Islam lebih banyak dikenal dengan menggunakan term "at-Tarbiyah", at-Ta"lim, at-Ta"dib dan Ar-Riyadah". ${ }^{3}$ Walaupun term tersebut mempunyai makna yang berbeda, karena perbedaan teks dan konteks kalimatnya, walaupun dalam hal-hal tertentu, term-term tersebut mempunyai kesamaan makna.

Kata Tarbiyah berakar pada kata rabb. Kata tersebut menurut al-Raghib alAsfahany mempunyai arti "insha al-sha"ihalan fahalun ila hadd al-tamam" (mengembangkan atau menumbuhkan sesuatu setahap demi setahap sampai pada batas yang sempurna). 4 Fahrur Razi memberi makna attanmiyah(pertumbuhan dan perkembangan) pada pengertian at-Tarbiyah. ${ }^{5}$ Kata tersebut selanjutnya digunakan oleh al-Qurean untuk berbagai hal antara lain digunakan untuk menerangkan salah satu sifat atau perbuatan Tuhan, yaitu rabb al-,Alaminyang diartikan sebagai Pemelihara, Pendidik, Penjaga, Penguasa dan Penjaga sekalian alam. ${ }^{6}$ Beberapa ahli bahasa memperkuat pendapat pengertian di atas, antara lain: Ibnu Abdillah Muhammad ibn Ahmad alAnshori al-Qurthubi dan Ustadz Karim alBastami.7 Selain kata rabb digunakan untuk arti sebagaimana disebut di atas, digunakan pula untuk arti yang obyeknya lebih terinci, yakni bahwa yang dipelihara, dididik, dan seterusnya itu ada yang berupa al-, arsh al-azim, yakni "arsh yang demikian besar, al-mashriq, yakni ufuk timur tenmpatnya terbit matahari, aba"ukum awwalun yakni nenek moyang para pendahulu orang-orang kafir Quraisy, al-maghrib yakni ufuk barat tempat terbenamnya matahari, al-baladah yakni negeri yang dalam hal ini adalah Makkah alMukarramah, al-bait yakni rumah yang dalam hal ini Baitullah (Ka'bah), dan al-Falaq. ${ }^{8}$ Sedangkan menurut Syed Muhammad Al-Naquib Al-Attas mengartikan at-tarbiyah dengan robba terutama terma rabbayani ${ }^{9}$ dengan memberi makan, memelihara, mengasuh, mempertumbuhkan, memproduksi

\footnotetext{
${ }^{3}$ Karim al-Bastani, et. al., Al--Munjil Fi Lughah wa A“lam, Beirut: Darul Masyriq, XXVI/1875, p. 287; dan Hussein Bahreisi, Ajaran-Ajaran Akblak Imam Al-Ghazali, Surabaya: Al-Ikhlas, 1981, p. 74.

${ }^{4}$ Lihat: Al-Raghib al-Ashfahany, Mu"jam Mufradat li Mufradat li Alfazal-Qur"an, Beirut: Dar al-Fikr, t.t., 198.

${ }^{5}$ Robba merupakan fonem yang seakar dengan at-tarbiyah yang mempunyai makna at-tanmiyah. Lihat: Fahrur Razi Tafsir Fahrur Razi, Taherana: Darul Kuthubi ilmiah, juz xxi, 151;

${ }^{6}$ Lihat: QS, al-Fatihah, 1:2; al-Baqarah, 2:131; al-Maidah, 5:28; al-An'am, 6:45, 71, 162, dan 164; Al-A'raf, 7:54 dan lain-lainnya.

7 Ibnu Abdillah Muhammad ibn Ahmad al-Anshari al-Qurthubi, Tafsir Al-Qurthubi, Kairo: Barus Syabi, Juz 1, p.

${ }^{8}$ al-Arsh al-Azim, Lihat antara lain QS, al-Taubah, 9:129; al-Mashriq, antara lain di al-Shaffat, 37:5; aba' ukum al-awwalun, antara lain di al-Shaffat, 37:126; al-Maghrib antara lain di alRahman, 55:17, al-Baldah antara lain al-Naml, 27:91, al-Baqarah, 2:126, al-Bait antara di Quraisy, 106:3 dan al-Falaq antara lain di al-Falaq, 112:1.

${ }_{9}$ QS, al-Isra, 17:21; asy-Syu'ara, 26:18.
}

| RI'AYAH, Vol. 4 No. 01 Januari-Juni 2019 
dan menjinakkan. ${ }^{10}$ Pengertian tersebut bertentangan dengan pendapat Fahrur Razi dalam mengartikan term robbayani tidak hanya ajaran bersifat ucapan (domain kognitif), tetapi juga meliputi pengajaran tingkah laku (domain afektif). Sebagaimana Sayyid Qutb menafsirkan fonem robbayani sebagai pemeliharaan anak serta menumbuhkan kematangan sikap mentalnya. ${ }^{11}$ Beberapa ayat tersebut di atas menunjukkan dengan jelas, bahwa kata rabb sebagaimana disebutkan dalam al-Qurean ternyata digunakan untuk menunjukkan obyek yang bermacammacam, yang dalam hal ini meliputi benda-benda yang bersifat fisik maupun non-fisik. Dengan demikian, pendidikan meliputi pemeliharaan terhadap seluruh makhluk Tuhan.

Adapun kata Ta'lim yang berasal dari akar kata allamadalam konotasi pengertian dengan pendidikan memberi pengertian sebagai berikut:

1. Muhammad Rosyid Ridlo memberikan arti sebagai proses transmisi berbagai ilmu pengetahuan pada jiwa individu tanpa adanya batasan dan ketentuan tertentu. ${ }^{12}$

2. Ar-Raghib al-Asfahany memberikan arti secara khusus, yaitu untuk menunjukkan sesuatu yang dapat diulang dan diperbanyak sehingga menghasilkan bekas atau pengaruh pada diri seseorang. Dan ada pula yang mengaitkan bahwa kata tersebut digunakan untuk mengingatkan jiwa agar memperoleh gambaran mengenai arti tentang sesuatu, dan terkadang kata tersebut dapat pula diartikan pemberitahuan. ${ }^{13}$

3. Abdu Fatah Jalal memberi pengertian sebagai proses pembenahan pengetahuan, pemahaman, pengertian, tanggungjawab, dan penanaman amanah, sehingga terjadi tazkiyah(penyucian) atau pembersihan diri manusia dari segala kotoran dan menjadikan diri manusia itu berada dalam suatu kondisi yang memungkinkan untuk menerima al-hikmah serta mempelajari segala apa yang bermanfaat baginya dan yang tidak diketahuinya. ${ }^{14}$

4. Syed Muhammad al-Naquib Al-Attas memberikan makna at-ta'lim dengan pengajaran tanpa adanya pengenalan secara mendasar. Namun apabila at-ta'lim disinonimkan dengan attarbiyah, at-ta'lim mempunyai makna pengenalan tempat segala sesuatu dalam sebuah sistem. ${ }^{15}$

5. Muhammad Athiyah Al-Abrasy memberikan pengertian at-ta'lim yang lebih khusus dibandingkan dengan at-tarbiyah, karena at-ta'lim hanya merupakan upaya menyiapkan individu dengan mengacu pada aspek-

\footnotetext{
${ }^{10}$ Syed Muhammad Al-Naquib Al-Attas, Konsep Pendidikan Dalam Islam, p. 66.

${ }^{11}$ Lihat: Fahrur Razi Tafsir Fahrur Razi, Taherana: Darul Kuthubi ilmiah, juz XXI, p. 151; dan Sayyid Qutb, Tafsir Fi Zilali Qur-an, Beirut: Ahyal, Juz XV, 15.

${ }^{12}$ Muhammad Rasyid Ridlo, Tafsir al-Manar, Mesir: Darul Manar, IV/1373, Juz, 262.

${ }^{13}$ Lihat: Al-Raghib al-Ashfahany, Mujam Mufradat li Mufradat li Alfaz al-Qur-an, Beirut: Dar al-Fikr, t.t., p. 198.

${ }^{14}$ Abdul Fatah Jalal, Minal Usulat-Tarbawiyah Fil Islam, Mesir: Darul Kutub Misriyyah, 1977, 17.

${ }^{15}$ Syed Muhammad Al-Naquib Al-Attas, Konsep Pendidikan Dalam Islam, Suatu Rangka Pikir Pembinaan Filsafat Pendidikan Islam, Bandung: Mizan, 1984.
}

| RI'AYAH, Vol. 4 No. 01 Januari-Juni 2019 
aspek tertentu saja, sedangkan at-tarbiyah mencakup keseluruhan aspek pendidikan. ${ }^{16}$

Akan tetapi kalau dilihat penggunaan At-ta'lim atau allama dalam firman Allah swt. di AlQur'an, yaitu: Terkadang digunakan oleh Tuhan untuk menjelaskan pengetahuan-Nya yang diberikan kepada sekalian manusia, menerangkan bahwa Tuhan Maha Mengetahui terhadap segala sesuatu yang ada pada manusia, Tuhan mengetahui tentang orang-orang yang mengikuti petunjuk Tuhan.17

Dari informasi ini terlihat bahwa kata ta'lim di dalam al-Qur"ean mengacu kepada adanya sesuatu berupa pengetahuan yang diberikan kepada seseorang. Jadi sifatnya intelektual. Sedangkan kata tarbiyah lebih mengacu kepada bimbingan, pemeliharaan, arahan, penjagaan, dan sifatnya pembentukan kepribadian.

Sedang kata ta'dib yang berakar pada kata addaba tidak dijumpai dalam al-Qur"an. Kata tersebut dijumpai dalam hadits antara lain yang berbunyi: addabani rabbifa ahsana ta' dibi, artinya: Tuhanku telah mendidikku, dan telah membuat pendidikanku itu sebaik-baiknya. 18 Halini mengandung pengertianpada pengenalan dan pengakuan yang berangsur-angsur ditanamkan kepada manusia tentang tempat-tempat yang tepat dari segala sesuatu di dalam tatanan penciptaan sedemikian rupa, sehingga membimbing ke arah pengenalan dan pengakuan kekuasaan dan keagungan Tuhan di dalam tatanan wujud dan keberadaanya. Kemudian, Naquib alAttas berpendapat bahwa kata yang paling tepat untuk mewakili kata pendidikan adalah $t a^{\prime} d i b$, sementara istilah tarbiyah dinilainya terlalu luas, yakni mencakup pendidikan utuk hewan. Sedangkan ta'dib sasaran pendidikannya adalah manusia. ${ }^{19}$

Sebaliknya, term ar-Riyadhoh hanya khusus dipakai oleh Imam AlGhazali dengan istilahnya "Riyadatussibyan" artinya pelatihan terhadap pribadi individu pada fase anak-anak. Imam Al-Ghazali dalam mendidik anak, lebih menekankan aspek afektif dan psikomotoriknya dibandingkan dengan aspek kognitif. 20

Uraian di atas memperlihatkan dengan jelas bahwa di kalangan para ahli pendidikan Islam sendiri masih belum terdapat kesepakatan mengenai penggunaan dari keempat istilah tersebut untuk mewakili kata pendidikan. Untuk menghindari pembicaraan yang berkepanjangan yang dasarnya hanya pada segi permainan kosakata, maka Konferensi Internasional Pendidikan Islam di Universitas King Abdul Aziz, Jeddah, pada tahun 1977, belum berhasil merumuskan secara jelas tentang definisi pendidikan, khususnya

\footnotetext{
${ }^{16}$ Muhammad Athiyah Al-Abrasyi, Rubut Tarbiyah wa Ta'lim, Saudi Arabiyah: Dar ul Ahya, t.t., 7.

${ }^{17} \mathrm{QS}$ Al-Baqarah, 2:260; Hud, 11:79; Al-Baqarah, 2:143.

${ }^{18}$ Hadits ini antara lain dikutip dan dijadikan motto oleh Muhammad Quthb untuk bukunya yang berjudul Sistem Pendidikan Islam, yang diterjemahkan oleh Salman Harun dan diterbitkan oleh PT. Al-maa'rif, Bandung.

${ }^{19}$ Syed Muhammad An-Naquib Al-Attas, Kosep Pendidikan Islam, 53-66.

${ }^{20}$ Hussein Bahreisi, Ajaran-ajaran Akblak Imam Al-Ghazali, Surabaya: Al-Ikhlas, 1981, 24.
}

| RI'AYAH, Vol. 4 No. 01 Januari-Juni 2019 
menurut Islam. Dalam bagian Rekomendasi Konferensi tersebut, para peserta hanya membuat kesimpulan bahwa pengertian pendidikan menurut Islam ialah keseluruhan pengertian yang terkandung dalam istilah-istilah tersebut. ${ }^{21}$

Namun demikian, istilah tersebut sebenarnya mengesankan adanya perbedaan antara satu dengan lainnya. Istilah ta'lim mengesankan proses pemberian bekal pengetahuan, sedangkan istilah tarbiyah mengesankan proses pembinaan dan pengarahan bagi pembentukan kepribadian dan sikap mental, sementara istilah ta'dib mengesankan proses pembinaan terhadap sikap moral dan etika dalam kehidupan yang lebih mengacu pada peningkatan martabat manusia.

\section{Dasar Pendidikan}

Dasar pendidikan dimaksudkan sebagai sumber nilai kebenaran dan kekuatan yang dapat menghantarkan pada aktivitas yang dicita-citakan. Nilai yang terkandung harus mencerminkan nilai yang universal yang dapat dikonsumsikan untuk keseluruhan aspek kehidupan manusia, serta merupakan standar nilai yang dapat mengevaluasi kegiatan yang selama ini berjalan.

Dasar pendidikan dapat di klasifikasikan menjadi: 1) Dasar ideal Pendidikan Islam, 2) Dasar operasional Pendidikan Islam. Kedua Dasar tersebut dapat dijabarkan sebagai berikut:

\section{Dasar Ideal Pendidikan Islam}

Dasar ideal ini merupakan hirarki yang tidak dapat diubah susunannya, walaupun hakikat keseluruhan dasar itu telah mengkristal dalam ajaran Al-Qur'an dan As-Sunnah. Dr. Said Ismail Ali berpendapat bahwa susunan hirarkis yang dimaksud adalah sebagai berikut: a) AlQur'an b) Sunnah Nabi Saw c) Kata-kata Sahabat d) Kemasyarakatan umat (sosial) e) Nilai-nilai dan adat kebiasaan masyarakat f) Hasil Pemikiran para pemikir Islam. ${ }^{22}$

a. Al-Qur'an

Al-Qur"an diartikan sebagai "Kalam mulia yang diturunkan oleh Allah kepada jiwa Nabi yang paling sempurna (Muhammad saw.), yang diajarannya mencakup ilmu pengetahuan yang tinggi dan merupakan sumber yang mulia yang esensial tidak dapat dimengerti kecuali bagi orang yang berjiwa suci dan berakal cerdas" ${ }^{23}$

Al-Qur'an merupakan sumber nilai yang absolut, yang eksistensinya tidak mengalami perubahan walaupun interpretasinya dimungkinkan mengalami perubahan sesuai dengan konteks zaman, keadaan, dan tempat. Al-Qur'an dapat menjadi dasar pendidikan Islam karena di dalamnya dimuat sebagai berikut: a. Sejarah Pendidikan Islam,

\footnotetext{
${ }^{21}$ Pembahasan istilah dalam konferensi tersebut hanya tertuju pada Tarbiyah, Ta'lim dan Ta'dib. Lihat: Abudin Nata, Filsafat Pendidikan Islam I, Jakarta: Logos Wacana Ilmu, 1997, 8.

${ }_{22}$ Umar Muhammad al-Toumy Al-Syaibany, Falsafah Pendidikan Islam, terj. Hasan Langgulung, Jakarta: Bulan Bintang, 1979.

${ }^{23}$ Muhammad Rasyid Ridlo, Tafsir al-Manar, Mesir: Darul Manar, IV/1373, Juz, 262
}

| RI'AYAH, Vol. 4 No. 01 Januari-Juni 2019 
b. merupakan pedoman normative-teoritis dalam pelaksanaan pendidikan Islam. ${ }^{24}$

b) Sunnah Nabi saw.

Sunnah dapat diartikan secara etimologis sebagai perilaku kehidupan (sirah) yang baik dan yang buruk, atas suatu jalan yang ditempuh (at-tariq al-Maslukah). Dalam arti termenologi, sunnah adalah segala yang dinukil dari Nabi saw., baik berupa perkataan, perbuatan, penetapan atau selain itu. ${ }^{25}$

c) Kata-kata Sahabat Nabi/madhab sahabi

Istilah sahabat nabi dalam Islam mempunyai konotasi makna orang yang pernah berjumpa dengan Nabi sedangkan ia sendiri telah beriman dan mati dalam membawa iman pula. ${ }^{26}$

Upaya sahabat Nabi dalam bidang pendidikan Islam sangat menentukan perkembangan pemikiran pendidikan dewasa ini. Upaya yang dilakukan oleh Abu Bakr dengan membukukan Al-Qur'an yang digunakan sumber utama pendidikan Islam, kemudian diteruskan Umar Ibn Khathab sebagai bapak reaktuator terhadap ajaran Islam. Tindakan Umar Ibn Khathab itu sebagai salah satu model dalam membangun strategi kependidikan dalam perspektif pembaharuannya. Dilanjukan dengan Usman Ibn Affan yang mempersatukan sistematika penulisan Al-Qurean. Sebagai puncaknya, Ali Ibn Abi Thalib yang banyak merumuskan konsep-konsep kependidikan, seperti bagaimana seyogyanya etika anak didik pada pendidiknya, atau sebaliknya. ${ }^{27}$

d) Kemasalahatan masyarakat/Masalihul Mursalah

Pengertiannya adalah menetapkan peraturan/ketentuan undangundang yang tidak disebutkan dalam Al-Qur"ean dan As-Sunnah atas pertimbangan penarikan kebaikan dan penolakan kerusakan dalam kehidupan masyarakat. ${ }^{28}$

e) Nilai-nilai dan Adat Istiadat Masyarakat/Urf

Pengertian Urf adalah suatu perbuatan dan perkataan yang menjadikan jiwa merasa tenang dalam mengerjakan suatu perbuatan, karena sejalan dengan akal sehat dan diterima oleh tabiat yang sejahtera. 29 Sesungguhnya nilai-nilai tradisi setiap masyarakat merupakan realitas yang multi-komplek dan dialektis. Nilai-nilai itu

\footnotetext{
${ }^{24}$ QS, Al-Baqarah: 31

25 Syed „Alawi Ibnu Syed „Abbas Al-Maliky Al-Husny, Fathul Qorib Mujib „Ala Tahdhib, Targhib wa Tarbib, Mekah: Sahr IV, 1983, 5.

${ }_{26}$ Muhammd Ibnu „Alawi Al-Maliki Al-Husny, Qowaidul Asasiyah fi Ilmi Mustalah Hadith, Makkah: Sahr, I, 1402, 57.

${ }^{27}$ Burhanul Islam As-Zanuji, Talim Mutaallim fi Tariq Ta'allum, Surabaya: Salim Nabhan, t.th., 15.

${ }^{28}$ Abdul Wahab Khalaf, Masadir At-Tashri Al-Islami Fima la maso fih, Kuwait: Darul Qolam, III, 1972, 85-86.

${ }^{29}$ Bandingkan Abdul Mujib H., Al-Qowaiidul Fiqhiyah (kaidah-kaidah Ilmu Fiqh), Yogyakarta: Nur Cahaya, 1980, 41.

${ }^{30}$ Franz Magnis Suseno, Berfilsafat dari Konteks, Jakarta: Gramedia, 1991, 86-87.
}

| RI'AYAH, Vol. 4 No. 01 Januari-Juni 2019 
mencerminkan kekhasan masyarakat, sekaligus sebagai pengejawantahan nilai-nilai universal manusia. ${ }^{30}$

Tidak semua nilai tradisi masyarakat dapat dijadikan ideal pendidikan Islam. Nilai itu dapat diterima setelah melalui seleksi terlebih dahulu, misalnya:

1. Tidak bertentangan dengan ketentuan nash, baik dari Al-Qur'an maupun As-Sunnah.

2. Tradisi yang berlaku tidak bertentangan dengan akal sehat dan tabiat yang sejahtera, serta tidak mengakibatkan kedurhakaan, kerusakan, dan kemudaratan. ${ }^{31}$

f) Hasil Pemikiran Muslim/Ijtihad

Abu Hamid Hakim mendefinisikan ijtihaddengan upaya yang sungguh-sungguh dalam memperoleh hukum syara"e, berupa konsep yang operasional, melalui metode istinbat(deduktif maupun induktif) dari al-Qurean dan As-sunnah. ${ }^{32}$ Hasil pemikiran para mujtahid dapat dijadikan dasar pendidikan Islam, terlebih lagi jika ijtihad itu menjadi consensus umum (ijma'), eksistensinya semakin kuat.

\section{Dasar Operasional Pendidikan Islam}

Dasar operasional pendidikan Islam merupakan dasar yang terbentuk sebagai aktualisasi dari dasar ideal. Dasar ini dapat diklasifikasikan menjadi enam macam, yaitu: a) Dasar histories; b) dasar sosial; c) dasar ekonomi; d) dasar politik dan administratif; e) dasar psikologis; dan f) dasar filosofis.

a. Dasar histories

Dasar yang memberi persiapan kepada pendidik dengan hasilhasil pengalaman masa lalu, undang-undang dan peraturanperaturannya, batas-batas dan kekurangankekurangannya.

b. Dasar Sosial

Dasar yang memberikan kerangka budaya yang pendidikannya itu bertolak dan bergerak, seperti memindah, memilih dan mengembangkannya.

c. Dasar ekonomi

Dasar ini memberi perspektif tentang potensi-potensi manusia dan keuangan, materi dan persiapan yang mengatur sumber-sumbernya dan bertanggung jawab terhadap anggaran pembelanjaan.

d. Dasar politik dan administrasi

Dasar yang memberi bingkai ideologi (aqidah) dasar, yang digunakan sebagai tempat bertolak untuk mencapai tujuan yang dicitacitakan dan rencana yang telah dibuat.

e. Dasar psikologis

\footnotetext{
${ }^{31}$ Baca: Masyfuk Zuhdi, Pengantar Hukum Islam, Jakarta: Haji

Masagung, 1990, 124.

32 Lihat: Abdul Hamid Hakim, Mabadi Auwaliyah, Jakarta:

Saadiyah Putra, t.th., 20.
} 
Dasar yang memberi informasi tentang watak pelajar-pelajar, guru-guru, cara-cara terbaik dalam praktik, pencapian dan penilaian dan pengukuran secara bimbingan. f. f. Dasar Filosofis

Dasar yang memberi kemampuan memilih yang terbaik, memberi arah suatu sistem, mengontrol dan memberi arah kepada semua dasardasar operasional lainnya. ${ }^{33}$

\section{Tujuan Pendidikan Islam}

Tujuan adalah dunia cita, yakni suasana ideal yang ingin diwujudkan, tujuan dapat berfungsi sebagai standar untuk mengakhiri usaha, serta mengarahkan usaha yang dilalui dan merupakan titik pangkal untuk mencapai tujuan-tujuan lain. Di samping itu, tujuan dapat membatasi ruang gerak usaha agar kegiatan dapat terfokus pada apa yang dicita-citakan dan yang terpenting lagi dapat memberi penilaian pada usaha-usahanya. ${ }^{34}$ Dalam tujuan pendidikan suasana ideal itu nampak pada tujuan akhir (ultimate aims of education), dan Tujuan akhir biasanya dirumuskan secara padat dan singkat.

\section{Aspek-aspek Perumusan Tujuan Pendidikan}

Perumusan tujuan pendidikan Islam harus berorientasi pada hakikat pendidikan yang meliputi beberapa aspeknya, misalnya tentang:

1. Tujuan dan tugas hidup manusia

Manusia hidup bukan karena kebetulan dan sia-sia, melainkan membawa tujuan dan tugas hidup tertentu. Tujuan diciptakan manusia adalah hanya untuk Allah swt. Indikasi tugasnya berupa ibadah (sebagai Abdullah) dan tugas sebagai wakil Allah di muka bumi (Khalifatullah). ${ }^{35}$

2. Memperhatikan sifat-sifat dasar (nature) manusia.

Konsep tentang manusia bahwa ia diciptakan sebagai khalifah Allah di bumi, serta untuk beribadah kepada Allah swt., penciptaan itu dibekali dengan berbagai macam fitrah yang berkecenderungan pada Al-Hanief (rindu akan kebenaran dari Tuhan) berupa agama Islam, 36 sebatas kemampuan dan kapasitas ukuran yang ada. ${ }^{37}$

3. Tuntutan Masyarakat

Tuntutan ini baik berupa pelestarian nilai-nilai budaya yang telah melembaga dalam kehidupan suatu masyarakat, maupun pemenuhan terhadap tuntutan kebutuhan hidupnya dalam mengantisipasi perkembangan dan tuntutan dunia modern.

\footnotetext{
${ }^{33}$ Lihat: Hasan Langgulung, Asas-asas pendidikan Islam, Jakarta: Rujukan Al-Husna, 1988, 6.7,12

${ }^{34}$ Ahmad D Marimba, Pengantar Filsafat Pendidikan, Bandung: Al-Marif, 1989, 45-46.

${ }_{35}$ Pernyataan tentang penciptaan manusia tidak sia-sia, Baca: QS, Ali Imran, 3:191; dan segala perbuatan manusia baik shalat, ibadah, hidup dan matinya manusia untuk Allah swt, QS, Al-An'am, 6:162.

${ }^{36} \mathrm{QS}, \mathrm{Al}-\mathrm{Baqarah}, 2: 30$; Adz-Dzaariyat, 51:56; Al-Kahfi, 18:29.

${ }^{37}$ Hasan Langgulung, Manusia dan Pendidikan, Suatu Analisa Psikologi dan Pendidikan, Jakarta: Rujukan Al-Husna, 1989,34.
} 
4. Dimensi-dimensi kehidupan ideal Islam.

Dimensi kehidupan ideal Islam mengandung nilai yang dapat meningkatkan kesejahteraan hidup manusia di dunia, untuk mengelola dan memanfaatkan dunia sebagai bekal kehidupan di akhirat. Dengan demikian demensi tersebut dapat memadukan antara kepentingan hidup duniawi dan ukhrowi. ${ }^{38}$ Keseimbangan dan keserasian antara kedua kepentingan hidup ini menjadi daya tangkal terhadap pengaruh-pengaruh negatif dari berbagai gejolak kehidupan yang menggoda ketentraman dan ketenangan hidup manusia baik yang bersifat spiritual, sosial, cultural, ekonomis, maupun ideologis dalam hidup pribadi manusia. ${ }^{39}$

\section{Formulasi Tujuan Pendidikan Islam}

Di antara para ahli pendidikan Islam berbeda secara redaksional dalam merumuskan pendidikan Islam, antara lain:

Al-Syaibani mengungkapkan bahwa formulasi pendidikan Islam harus sejalan dengan tujuan misi Islam itu sendiri, yaitu mempertinggi nilai-nilai akhlak, hingga mencapai tingkat akhlak al-karimah. ${ }^{40}$

Pernyataan di atas ditegaskan oleh Mohammad "Athiyah al-Abrasyi, bahwa pendidikan budi pekerti adalah jiwa dari pendidikan Islam, dan Islam telah menyimpulkan bahwa pendidikan budi pekerti dan akhlak adalah jiwa pendidikan Islam. Mencapai suatu akhlak yang sempurna adalah tujuan sebenarnya dari pendidikan Islam. ${ }^{41}$

Al-Ghazali menyatakan bahwa tujuan pendidikan Islam tercermin dalam dua segi, yaitu:

1. Insan purna yang bertujuan mendekatkan diri kepada Allah swt.

2. Insan purna yang bertujuan mendapatkan kebahagian hidup di dunia dan di akhirat. ${ }^{42}$ Ibnu Kholdun merumuskan tujuan pendidikan Islam terbagi atas dua macam, yaitu:

1. Tujuan berorientasi ukhrawiyaitu membentuk seorang hamba agar melakukan kewajiban pada Allah swt.

2. Tujuan yang berorientasi duniawi yaitu membentuk manusia yang mampu menghadapi segala bentuk kehidupan yang lebih layak dan bermanfaat bagi orang lain. ${ }^{43}$

Abdurrahman Saleh merumuskan pendidikan lebih terinci, dan dapat diklasifikasikan menjadi empat, yaitu:

\footnotetext{
${ }^{38} \mathrm{QS}, \mathrm{Al}-\mathrm{Q} a \mathrm{sh} a \mathrm{sh}, 28: 77$.

${ }^{39}$ H.M. Arifin, Kapita Selekta Pendidikan Islam dan Umum, Jakarta: Bumi Aksara, 1991, 4.

${ }^{40}$ Umar Muhammad al-Toumy al-Syaibani, Falsafah Pendidikan Islam, terj. Hasan Langgulung, Jakarta: Bulan Bintang, 1979.

${ }^{41}$ Pada definisi ini nampak bahwa gambaran manusia yang ideal yang harus dicapai melalui kegiatan pendidikan adalah manusia yang sempurna akhlaknya. Hal ini nampak sejalan dengan misi kerasulan Nabi Muhammad saw., yaitu untuk menyempurnakan akhlak yang mulia (li utammima makrima al-akblak). Baca: Mohammad Athiyah al-Abrasyi,

${ }^{42}$ Fathiyah Hasan Sulaiman, Sistem Pendidikan Versi Al-Ghazali, terj. Fathur Rahman, Bandung; AlMa"earif, 1986, 24.

${ }^{43}$ Muhammad Athiyah Al-Abrasyi, At-Tarbiyah wa Falasifuba, Mesir: Al-Nalaby, 1969, 284.
}

| RI'AYAH, Vol. 4 No. 01 Januari-Juni 2019 
1. Tujuan pendidikan jasmani (ahdaf al-jismiyah); mempersiapkan diri manusia sebagai pengemban tugas khalifah di bumi, melalui pelatihan (training) ketrampilan-ketrampilan fisik. ${ }^{44}$

2. Tujuan pendidikan rohani (ahdaf ar-ruhaniayah); Meningkatkan jiwa dari kesetiaan yang hanya kepada Allah Swt semata dan melaksanakan moralitas Islami yang diteladani oleh Nabi Saw, dengan berdasarkan pada cita-cita ideal dalam Al-Qur'an. Indikasi pendidikan rohani adalah tidak bermuka dua, berupaya memurnikan dan menyucikan diri manusia secara individual dari sikap negatif. ${ }^{45}$ Inilah yang disebut dengan "tazkiyah" atau purifikasi dalam "hikmah".

3. Tujuan pendidikan akal (ahdaf al-'Aqliyah); Pengerahan intelektual untuk menemukan kebenaran dan sebab-sebabnya dengan telaah tandatanda kekuasaan Allah Swt dan menemukan pesan-pesan ayat-ayat-Nya yang membawa iman kepada Sang Pencipta.

Tahapan pendidikan akal ini adalah:

a. Pencapaian kebenaran ilmiah (ilmu Yaqin).

b. Pencapaian kebenaran emperis (ainul Yaqin). ${ }^{46}$

c. Pencapaian kebenaran metaemperis atau mungkin lebih tepatnya sebagai kebenaran filosofis-transendental (haqqul yaqin). ${ }^{47}$

4. Tujuan pendidikan sosial (ahdaf al-ijtimaiyah); pembentukan kepribadian yang utuh dari roh, tubuh dan akal. Identitas individu di sini tercantum sebagai 'an-Nas' yang hidup pada masyarakat yang plural (majemuk). ${ }^{48}$

Ali Ashraf mengatakan bahwa tujuan pendidikan Islam merupakan "terwujudnya penyerahan mutlak kepada Allah, pada tingkat individu, masyarakat, dan kemanusiaan pada umumnya". Dan tujuan umum tersebut merupakan kristalisasi dari tujuan khusus pendidikan Islam, yaitu:

1.Mengembangkan wawasan spiritual yang semakin mendalam, serta mengembangkan pemahaman rasional mengenai Islam dalam konteks kehidupan modern.

2. Membekali anak muda dengan berbagai pengetahuan dan kebajikan, baik pengetahuan praktis, kekuasaan, kesejahteraan, lingkungan sosial, dan pembangunan sosial.

3. Mengembangkan kemampuan pada diri anak didik untuk menghargai dan membenarkan superioritas komparatif kebudayaan dan peradaban Islami di atas semua kebudayaan lain.

4. Memperbaiki dorongan emosi melalui pengalaman imajinatif, sehingga kemampuan kreatif dapat berkembang dan berfungsi mengetahui norma-norma Islam yang benar dan yang salah.

\footnotetext{
${ }^{44}$ QS, Al-Baqarah, 2:247; Al-Anfal, 8:60.

45 QS, Ali Imran, 3:19

${ }^{46}$ QS, At-Takasur, 102:5-7

${ }^{47}$ QS, Al-Waqi'ah, 56: 95; al-Haaqah,

${ }^{48}$ Abdurrahman Saleh Abdullah, Educational Theory: Qur"anic Outlook, Mekah: Umm Al-Qora

University, 1982, 119-126.
} 
5. Membantu anak yang sedang tumbuh untuk belajar berpikir secara logis dan membimbing proses pemikirannya dengan berpijak pada hipotesis dan konsep-konsep tentang pengetahuan yang dituntut.

6. Mengembangkan wawasan relational dan lingkungan sebagaimana yang dicita-citakan dalam Islam, dengan melatih kebiasan yang baik.

7. Mengembangkan, menghaluskan, dan memperdalam kemampuan berkomunikasi dalam bahasa tulis dan bahasa lisan. ${ }^{49}$

Sedangkan rumusan tujuan pendidikan Islam yang dihasilkan Konperensi Pertama tentang Pendidikan Islam di Makkah tahun 1977, 50 adalah:

"Pendidikan Islam seharusnya bertujuan mencapai pertumbuhan yang seimbang dalam kepribadian manusia secara total melalui latihan semangat, intelek, rasional diri, perasaan dan kepekaan rasa tubuh. Karena itu pendidikan Islam seharusnya memberikan jalan bagi pertumbuhan manusia dalam segala aspeknya secara spiritual, intelektual, imajinatif, fisikal, ilmiah, linguistik, baik secara individual maupun secara kolektif disamping memotivasi semua aspek tersebut ke arah kebaikan dan kesempurnaan" ${ }^{51}$

Rumusan tersebut dikuatkan dengan rumusan yang dihasilkan Komperensi Kedua tentang Pendidikan Islam di Islamabad, yaitu:

"Pendidikan seharusnya bertujuan mencapai pertumbuhan yang seimbang dalam kepribadian manusia secara total melalui pelatihan spiritual, kecerdasan, rasio, perasaan, dan panca indera. Oleh karena itu, pendidikan seharusnya memberikan pelayanan bagi pertumbuhan manusia dalam segala aspeknya yang meliputi aspek spiritual, intelektual, imajinasi, fisik, ilmiah, linguistik, baik secara individu, maupun secara kolektif di samping memotivasi semua aspek tersebut ke arah kebaikan dan pencapaian kesempurnaan. Tujuan utama pendidikan bertumpu pada terealisasinya ketundukan kepada Allah swt., baik dalam level individu, komunitas, dan manusia secara luas". ${ }^{52}$

\section{Fokus Esensial Tujuan Pendidikan}

Dari berbagai rumusan tujuan pendidikan tersebut, dapat disimpulkan tujuan pendidikan Islam pada hakikatnya terfokus pada tiga bagian esensial, yaitu:

1. Terbentuknya "insan kamil/ manusia universal/holistic person", 53 yang terproyeksi secara qur"eani, yaitu:

a. Sikap Kekeluargaan, persaudaraan dan sikap egalitarian. ${ }^{54}$

b. Sebagai makhluk yang berakal dan dimulyakan Allah swt. ${ }^{55}$

${ }^{49}$ Ashraf, Horison Baru Pendidikan Islam, terj. Sayid Husein Tash, Jakarta: Rujukan Firdaus, 1989, 3 dan 130.

50 Ali Ashraf, Horison Baru Pendidikan Islam, xi.

51 Ibid., 25.

${ }^{52}$ H.M. arifin, Kapita Selekta Pendidikan Islam dan Umum, 4.

53 Dawam Rahardjo, penyunting, Insan Kamil, Konsep Manusia menurut Islam, Jakarta: Temprint, 1989, 26.

${ }^{54}$ Baca: QS, Al-Hujarat, 49:10-13.

| RI'AYAH, Vol. 4 No. 01 Januari-Juni 2019 
c. Sikap kreatif yang dapat menumbuhkan gagasan baru dan bermanfaat bagi kemanusiaan. 56

d. Sikap keterbukaan yang menumbuhkan prestasi kerja dan pengabdian mendahului prestasi. ${ }^{57}$

e. Sikap monokotomis yang menumbuhkan integralisme sistem ilahiyah ke dalam sistem insaniah dan sistem kauniyah.

f. Adanya keseimbangan pribadi yang menumbuhkan kebijakan dan kearifan dalam mengambil keputusan. ${ }^{58}$

g. Kasih sayang yang menumbuhkan karakter dan aksi solidaritas dan sinergi. ${ }^{59}$

h. Sikap alturistik yang menumbuhkan perilaku kebersamaan dalam mendahulukan orang lain. ${ }^{60}$

i. Sikap demokratis yang menumbuhkan rasa penghargaan dan penghormatan terhadap persepsi dan aspirasi yang berbeda. ${ }^{61}$

j. Rasa keadilan yang menimbulkan persamaan hak serta perolehan. ${ }^{62}$

k. Sikap disiplin yang menimbulkan keteraturan dan ketertiban dalam kehidupan.63

1. Rasa kemanusiaan yang menumbuhkan usaha menghindarkan diri dari dominasi dan eksploitasi. ${ }^{64}$

m. Rasa penuh kesederhanaan yang menumbuhkan rasa dan karsa menjauhkan diri dari pemborosan. 65

n. Intelektual dan terpelajar yang menumbuhkan daya imajinasi dan daya cipta. ${ }^{66}$

o. Mempunyai nilai tambah (value added) ${ }^{67}$

2. Terciptanya InsanKaffah yang memiliki dimensi-dimensi religius, budaya, dan ilmiah.

a. Dimensi religius, yaitu manusia merupakan makhluk yang mengandung berbagai misteri dan tidak dapat direduksikan kepada faktor semata-mata. Dengan demikian, manusia dapat

${ }^{55} \mathrm{QS}$, Al-Anfal, 8:4; An-Nahl, 16:70; Al-Isra ${ }^{e e}$ 17:23; Al-Furqan, 25:72; Al-Ahzab, 33:44; Al-Hujarat, 49:13; Al-Waqieeah, 56:77; Al-Haaqah, 69:40; Al-Fajr, 89:17; dan Al-,Alaq, 96:3.

56

${ }^{57} \mathrm{QS}, \mathrm{Al}-\mathrm{An}$ 'am, 6:123.

${ }^{58} \mathrm{QS}$, Al-Baqarah, 2:25, 35; Ali Imran, 3:9; dan An-Nisa ${ }^{e e}, 4: 135$.

${ }^{59} \mathrm{QS}$, Ar-Rahman, 55:78.

${ }^{60} \mathrm{QS}$, Al-A'raf, 151, 156; Al-Anbiya', 21:107; Al-Isra', 17:24; Ar-Rum, 30:21; Luqman, 31:3;

Al-Fath, 48:29; ,Abasa, 80:31; dan Al-Balad, 90:17..

${ }^{61} \mathrm{QS}$, Al-Hasyr, 59:17.

${ }^{62} \mathrm{QS}$, At-Taubah, 9:60; Al-Hasyr, 59:7.

${ }^{63} \mathrm{QS}$, Al-Ma'idah, 5:8.

${ }^{64} \mathrm{QS}$, Al-Baqarah, 2:187; An-Nur, 24:51; dan Al-Hasyr, 59:18.

${ }^{65} \mathrm{QS}, \mathrm{Al}-\mathrm{Baqarah}, 2: 256$; dan Al-Mu'min, 40:8,9

${ }^{66} \mathrm{QS}$, Al-Baqarah, 2:165; Ali Imran, 3:15, 17, 185; An-Nisa" , 4:135; Al-A'raf, 7:131; dan An-

Nazi'at, 79:38,39

${ }^{67} \mathrm{QS}$, Al-Mujadilah, 58:11.

| RI'AYAH, Vol. 4 No. 01 Januari-Juni 2019 
dicegah untuk dijadikan angka, atomat, dan robot yang diprogramkan secara deterministis, tetapi tetap mempertahankan kepribadian, kebebasan akan martabatnya.

b. Dimensi budaya, manusia merupakan makhluk etis yang mempunyai kewajiban dan tanggung jawab terhadap kelestarian dunia seisinya. Dalam dimensi ini, manusia mendapatkan dasar untuk mempertahankan keutuhan kepribadiannya dan mampu mencegah arus zaman yang membawa pada desintegrasi dan framentasi yang selalu mengancam kehidupan manusia.

c. Dimensi ilmiyah, dimensi yang mendorong manusia untuk selalu bersikap obyektif dan realistis dalam menghadapi tantangan zaman, serta berbagai kehidupan manusia terbina untuk bertingkah laku secara kritis dan rasional, serta berusaha mengembangkan keterampilan dan kreativitas berpikir. ${ }^{68}$

3. Penyadaran fungsi manusia sebagai hamba, khalifah Allah, serta sebagai warasat Al-anbiya"dan memberikan bekal yang memadai dalam rangka pelaksanaan fungsi tersebut.

\section{Penutup}

Sesungguhnya realitas menyatakan bahwa pendidikan Islam di Indonesia khususnya hanya dipahami sebagai pembentukan qalbun salim', dan kurang perhatiannya dalam pengupayaan terwujudnya generasi yang memiliki "bastatan fil ilmi wal-jism". Dan sebaliknya sekolah-sekolah yang bergairah mengembangkan proses intelektualisasi menjadi kurang perhatiannya kepada masalah spiritualisasi dan disiplin moral yang islami.

Dengan demikian, wawasan pendidikan agamapun menjadi terbelah, disatu pihak mengarah kepada "priestly religion" (agama kewalian), dan di lain pihak mengarah kepada "prophetic religion" (agama kekaryaan). Pendidikan agama kerapkali hanya dipahami esensinya, tapi tidak dipahami substansinya. Prinsip filosofi pendidikan Qur"ani yang mempadukan "tilawah', tazkiyah', dan ,ta'lim" kurang memperoleh perhatian.

\section{Daftar Pustaka}

Ali, A. Mukti. Ijtihad, dalam Pandangan Muhammad Abduh, Ahmad Dahlan dan Muhammad Iqbal, Jakarta: Bulan Bintang, 1990.

Azra" Azyumardi. "Modernisasi Pendidikan Islam dan Epistemologi Ilmu", Makalah Seminar Internasional tentang Modernisasi Pendidikan Islam: Sistem, Metodologi dan Materi, ISID Gontor, 31 Agustus, 1996.

"Abd al-Baqy, Muhammad Fu“ad. al-Mu'jam al-Mufahras li Alfadz al-Qur'an al-Karim, Beirut: Dar al-Fikr, 1987.

Al-Attas, Syed Muhammad Al-Naquib. Konsep Pendidikan Dalam Islam, Suatu rangka pikir pembinaan filsafat pendidikan Islam, Bandung: Mizan, 1984.

al-Ashfahany, Al-Raghib. Mu'jam Mufradat li Mufradat li Alfaz al-Qur'an, Beirut: Dar al-Fikr, t.th.

${ }^{68} \mathrm{Al}-\mathrm{Hajj}, 22: 78 ;$ An-Najm, 53:39; dan Al-Hasyr, 59:18.

| RI'AYAH, Vol. 4 No. 01 Januari-Juni 2019 
Al-Attas, Syed Muhammad Al-Naquib. Konsep Pendidikan Dalam Islam, Suatu rangka pikir pembinaan filsafat pendidikan Islam, Bandung: Mizan, 1984.

Ahya', t.th. Al-Attas, Syed Muhammad An-Naquib. Konsep Pendidikan Islam.

Al-Syaibany, Umar Muhammad al-Toumy. Falsafah Pendidikan Islam, terj. Hasan Langgulung, Jakarta: Bulan Bintang, 1979.

As-Zarnuji, Burhanul Islam. Ta'lim Muta'allim fi Tariq Ta'allum, Surabaya: Salim Nabhan, t.t.

Abdul Wahab Khalaf, Mas'adir At-Tashri' Al-Islami Fima la masofih, Kuwait: Darul Qolam, III, 1972.

Abdul Mujib H., Al-Qowaiidul Fiqhiyah (kaidah-kaidah Ilmu Fiqh, Yogyakarta: Nur Cahaya, 1980.

Ashraf, Ali. Horison Baru Pendidikan Islam.

Bahreisi, Hussein. Ajaran-Ajaran Akhlak Imam Al-Ghazali, Surabaya: Al-Ikhlas, 1981.

H.A.R. Gibb, Modern Trends in Islam, New York: Octagon Book, 1978.

Hakim, Abdul Hamid. Maba'di'Auwaliyah, Jakarta: Sa'adiyah Putra, t.th.

H.M. Arifin, Kapita Selekta Pendidikan Islam dan Umum, Jakarta: Bumi Aksara, 1991.

Hasan, Muhammad Tholhah. Prospek Islam dalam Menghadapi Tantangan Zaman, Jakarta: Bangun Prakarya, II/1986.

Ibnu Abdillah Muhmmad ibn Ahmad al-Anshari al-Qurthubi, Tafsi $>$ r AlQurthubi, Kairo: Barus Sya"ebi, Juz 1.

Jalal, Abdul Fatah. Minal Us\}ul at-Tarbawiyah Fil Isla>m, Mesir: Darul Kutub Misriyyah, 1977

Karim al-Bastani, et. al., Al--Munjil Fi Lughah wa A "lam, Beirut: Darul Masyriq, XXVI/1875, p. 287;

Langgulung, Hasan. Manusia dan Pendidikan, Suatu Analisa Psikologi dan Pendidikan, Jakarta: Rujukan Al-Husna, 1989.

Langgulung, Hasan. Asas-asas pendidikan Islam, Jakarta: Rujukan Al-Husna, 1988.

Muhammad Athiyah Al-Abrasyi, Ru>hut Tarbiyah wa Ta'li>m, Saudi Arabiyah:

Dar> ul

Muhammad Athiyah al-Abrasyi, Dasar-dasar Pokok Pendidikan Islam, terj. Bustami A. Ghani dan Djohar Bahry L.I.S. dari Al-Tarbiyah al-Islamiyah, Jakarta: bulan Bintang, 1974.

Muhammd Ibnu "Alawi Al-Maliki Al-Husny, Qowaidul Asasiyah fi Ilmi Must\}alah Hadi>th, Makkah: Sahr, I, 1402.

Marimba, Ahmad D. Pengantar Filsafat Pendidikan, Bandung: Al-Ma“rif, 1989.

Nata, Abudin. Filsafat Pendidikan Islam I, Jakarta: Logos Wacana Ilmu, 1997.

Rahardjo, Dawam. penyunting, Insan Kamil, Konsep Manusia menurut Islam, Jakarta: Temprint, 1989.

Razi. Fahrur. Tafsir Fahrur Razi, Taherana: Darul Kuthubi Ilmiah, juz XXI.

Ridlo, Muhammad Rasyid. Tafsir al-Manar, Mesir: Darul Manar, IV/1373, Juz.

Syed "Alawi Ibnu Syed "Abbas Al-Maliky Al-Husny, Fathul Qorib Mujib ‘Ala Tahdhib, Targhib wa Tarhib, Mekah: Sahr IV, 1983.

Suseno, Franz Magnis. Berfilsafat dari Konteks, Jakarta: Gramedia, 1991. 
Sulaiman, Fathiyah Hasan. Sistem Pendidikan Versi Al-Ghazali, terj. Fathur Rahman, Bandung; AlMa"arif, 1986.

Umar Muhammad al-Toumy al-Syaibani, Falsafah Pendidikan Islam, terj. Hasan Langgulung, Jakarta: Bulan Bintang, 1979.

Qutb, Sayyid. Tafsir Fi Zilali Qur'an, Beirut: Ahyal, Juz XV.

Zuhdi, Masyfuk. Pengantar Hukum Islam, Jakarta: Haji Masagung, 1990. 